\title{
Is (Digital) History More than an Argument about the Past?
}

\section{Sherman Dorn}

Digital history is one more historiographical development since World War II that has challenged professional historians' definition of scholarship. While oral history and quantitative social history questioned the primacy of the written document and an elite focus, they and public history challenged the centrality of the researcher trained in academic history departments, and postmodernism undermined the authority of categories.[1] Of central concern is not whether the online world has infected humanities scholars in the United States with intellectual challenges (and status anxiety) but what new forms these are taking and the new professional and intellectual questions that digital history poses for historians.[2] As younger scholars worry about what "counts" as scholarship in an online universe, fearing that their senior colleagues will not respect anything other than monographs published by university presses, they partly replay previous waves of concern about professional legitimation.

Other chapters in this book illustrate the degree to which historians have continued to extend long-term changes in the discipline. The use of databases for notes is a more sophisticated version of electronic note taking that started with the first laptops. Mapping locations of community events and resources is an extension of quantitative social history's wrestling with data. Social history "from the bottom up" becomes more intense and more public when members of a community can more easily contribute to and discover work about their shared history. Creating video games out of history is in some ways a new version of the simulation role playing that teachers have used for decades.

Yet there are new opportunities and challenges that did not exist several decades ago. One is the ability to display primary sources and related data objects tied to those sources (tables, charts, and maps). As this volume's chapters by Stephen Robertson and John Theibault demonstrate, we are surrounded not just by the type of static images and data objects that historians have used to make arguments for years but by the ability to present audiences and interlocutors with manipulable objects, using software to allow readers to zoom in and move around, add or subtract data layers, change axes and variables, or set the data object in motion.[3]

The second feature that is new today is the spread of publishing platforms. One made Wikipedia possible. Another allowed this volume to have open peer review. At the same time, we have seen the erosion of the university press and subscription-based journal publishing as a viable commercial infrastructure for scholarship. The ease of disseminating gray literature and the growth of technological platforms for open-access publishing has undermined the case for continued reliance on subscription-based journals and university presses as gatekeepers with prepublication review. Intensified budget pressures on academic libraries have accelerated this discussion. The results have included more experimentation with alternative publishing pipelines and processes, as well as the challenges in intellectual authority captured by the chapters of this volume focusing on Wikipedia.[4] 
The third development is an artifact of the production of history in the first few decades of the “digital age" in historical scholarship: historians' first-mover advantage. It arose from funders having a range of interests; from a few senior historians, such as Roy Rosenzweig and Edward Ayers, using funding to develop diverse projects; and from the development of digitization technology far in advance of electronic book publication. The first-mover advantage for CDROM and then web projects leveraged interest in digitizing a range of sources at a time when it was neither technologically realistic nor professionally advantageous to try to publish long-form arguments online. Into that gap stepped funders, institutions, and individual academics and teams of scholars who had different priorities. At the same time, two developments at a national level in the United States created educational audiences as well as funding streams for a range of projects: a push for state-level standards in traditional K-12 academic subjects, including history, and a dedicated funding stream in the Teaching American History grant program.[5]

As a result of funding, entrepreneurial academics, ready audiences, and technological developments that benefited other formats over electronic books, the early production of digital history thus emphasized infrastructure over electronic equivalents of monographs. This firstmover advantage for new formats existed even when an individual digital project (such as Ayers's The Valley of the Shadow) was rooted in more conventional questions of scholarship. It required building idiosyncratic infrastructures that we usually associate with wealthy private or flagship public universities, but less prestigious public institutions, such as the City University of New York and George Mason University, built long-term structures where the new digital scholarship has thrived.

These developments happened in an era of existential threats to humanities scholarship whose roots lie far from the influence of technological change on the mechanics of scholarship. Long before Amazon.com, scholars have seen declining state support for public universities, vocational rhetoric surrounding the politics of higher education, the growing use of contingent academic labor, and increased pressures for scholarship at institutions that had focused on teaching only a few short years before.[6] Yet despite these ominous signs, the growth of digital scholarship provides an opportunity to understand our field in a richer way, and this understanding can serve both pragmatic and philosophical needs.

In one pragmatic sense, scholars whose work goes beyond the long-form argument need a way to help peers and administrators understand their work. Ernest Boyer's Scholarship

Reconsidered describes a general way of communicating for such understanding but is not sufficiently specific for each discipline.[7] Public historians have often struggled to communicate the meaning of their scholarship in research-oriented institutions, and the development of disciplinary support for their work and appropriate tenure and promotion standards has been relatively recent.[8]

In a second pragmatic sense, we need a better way to teach historical scholarship for undergraduates, not only for the ordinary reasons why history departments should be concerned about an undergraduate education, but also because we need better teaching of history in elementary and middle schools. Frequently, the second-to-last exposure to history for an elementary school teacher is her or his high school history classes, leaving the task of helping them understand history as a discipline to just one or two college courses. College history classes have little room for error in educating future teachers about what history is and can be. 
But if we use digital history projects as an opportunity to explore the nature of historical scholarship, that opportunity stretches beyond the practical issues of tenure, promotion, and exposing future teachers to disciplinary conventions. We can use the best of digital history work to redraw the discipline's boundaries. In attempting to battle the perception of history as a set of dates and names, or "just one damned thing after another," as Toynbee and Somervell put it, historians may have gone overboard in arguing that history is "an argument about the past," as a poster available to schoolteachers puts it (fig. 1). [9] The heterodox developments of the last few decades provide an opportunity to rethink the definition of historical scholarship. (See additional images for this essay at http://WritingHistory.trincoll.edu.) 


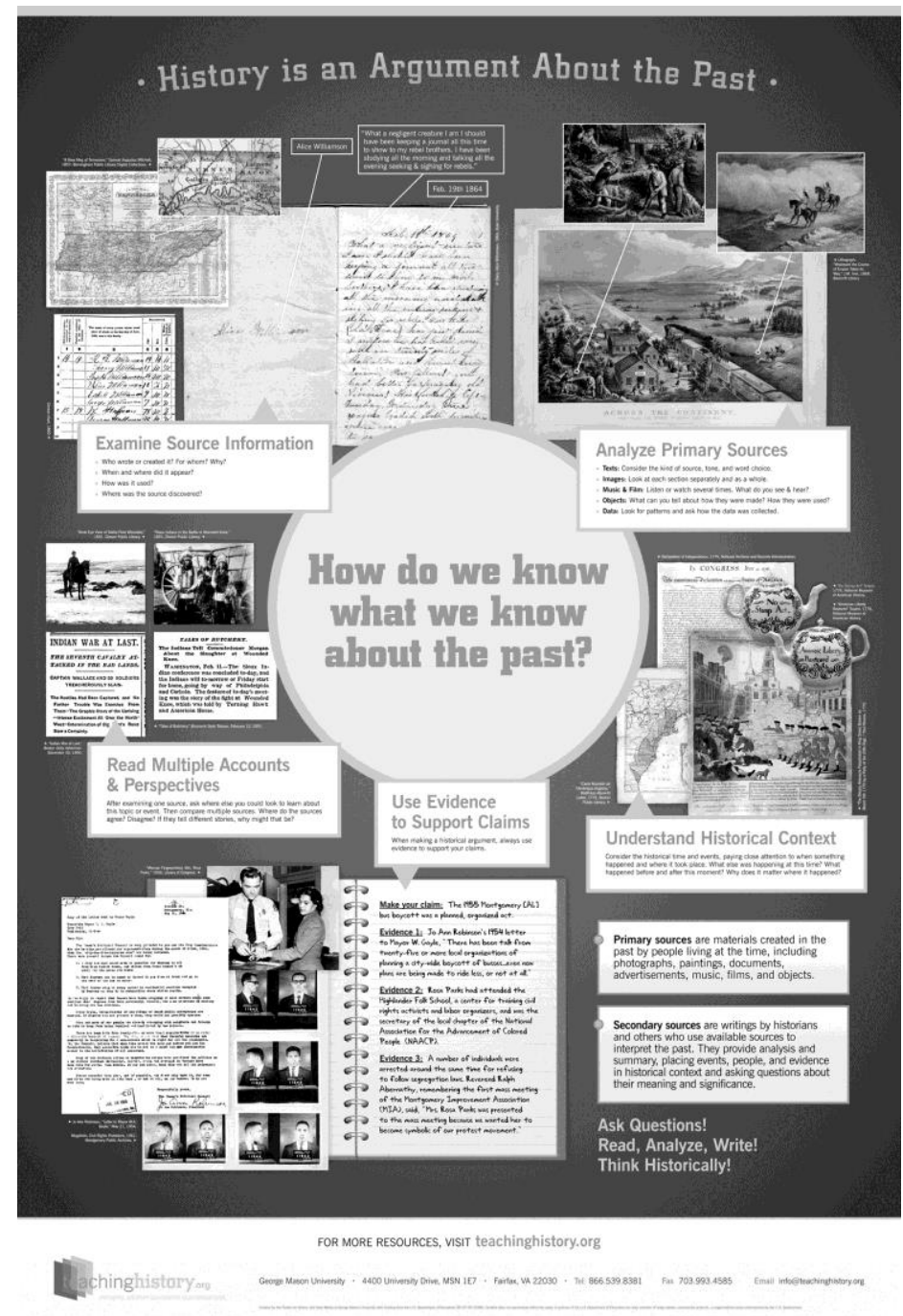

Fig. 1. Detail from the poster History Is an Argument about the Past (National History Education Clearinghouse, 2010). The emphasis in the poster is on using primary sources, understanding multiple perspectives, and putting issues in historical context. Missing is the type of work that often dominates digital history projects, including the one that created this poster. 


\section{Diverse Digital History}

Digital history projects have a broad range of quality and scope. This section provides brief descriptions of several projects that were created by professional historians, public historians, and other scholars.[10] It describes projects with differing polish and scope, beginning with two projects originally distributed on CD-ROM.[11]

Who Built America? was an extension of a two-volume social history textbook of the same name, with two CD-ROMs constructed and published in the 1990s.[12] The CD-ROMs provided a digital expansion of the common textbook sidebar presentation of primary sources, including audio and video clips of speeches as well as photographs and text or facsimile primary documents. Creating such a compilation is a labor-intensive process, in part because of extensive licensure issues involved in using media.[13]

The Valley of the Shadow was also an extension of a book project, in this case Edward L. Ayers's comparison of lives in two counties (Franklin County, Pennsylvania, and Augusta County, Virginia) before, during, and after the Civil War.[14] The project had an early online life, which Michael O'Malley and Roy Rosenzweig described in 1997 as a guided exploration of primary sources: "It allows students to construct their own narratives of life in both towns in the years before the war, but it seems to encourage narratives that follow the framework of Ayers's planned book." [15] In the years since, it has had various versions, including the transformation of the materials to a website that now serves as an official "archive" of the project.[16] The American Memory project displays both notable and little-known primary sources, photographs, and other artifacts in Library of Congress collections. Begun in the early 1990s with a pilot project and CD-ROMs,American Memory has continued as a sprawling online display of historical artifacts.[17] Individual items in the collection are displayed with archival metadata and can often be reached either as part of an organized presentation or through search tools.

The Papers of George Washington is a 43-year-old editing project that has produced more than 50 volumes of edited material (out of an anticipated 90). One digital version of the papers has public access. A more scholarly online version of the papers is available by individual or personal subscription as well as by purchase of individual printed volumes from the University of Virginia Press.[18] The general-access version contains a number of entrees to the primary sources, including chronological back/forward buttons that are akin to page turns. Hypercities (http://hypercities.com or http://hypercities.ats.ucla.edu/) is a geographic display platform for layered maps built on Google Maps and the ability to geocode pictures and maps. While other platforms built on Google Maps focus on current events (for example, Ushahidi, originally created to map Kenyan election violence in early 
2008), Hypercities focuses on the collection and curation of historical map information. It is the result of a 2008 MacArthur Foundation grant to Todd Presner of the University of California, Los Angeles, and Philip Ethington at the University of Southern California and has been used for a number of classes at various institutions as well as for scholarly research (such as Ethington's work on the history of Los Angeles).[19]

Europe, Interrupted is an online exhibit of the Inventing Europe project sponsored by the European Science Foundation and the Foundation for the History of Technology. It presents a structured path through collection items using the "exhibit" metaphor for presentation. It is an example of the type of exhibit produced using the open-source Omeka presentation software that public historians can customize for specific exhibits in museum collections.[20] History Matters is a website originally created in the late 1990s by the same organizations that created Who Built America? (the American Social History Project at the City University of New York and the Roy Rosenzweig Center for History and New Media at George Mason University). The website supports survey courses in U.S. history at the high school and undergraduate levels (and is subtitled The U.S. Survey Course on the Web), with a range of materials from selected primary sources and historical links to sample syllabi, exemplary student work, and other resources for teachers.[21]

\section{Digital History Undresses Scholarship}

The scope of these and other projects illustrate their breadth of purpose and the varied extent to which individual projects make an explicit argument, ranging from what one might call demonstrative argumentation (Europe, Interrupted and the individual Women and Social Movements websites, as Kathryn Kish Sklar and Thomas Dublin's chapter explains) to arguments-in-process (see Erickson's chapter), evidence sets from projects that are either at the "messing around" level (Hypercities) or more carefully curated for the public (The Valley of the Shadow), edited collections with an implicit argument (Who Built America?), edited collections without a demonstrative focus (American Memory and The Papers of George Washington), and infrastructure (whether for research, such as software packages specially built for humanities projects or the Integrated Public Use Microdata Series database, or for teaching, such as History Matters).[22]

This range uncovers history as more than a polished argument about the past. Presentation of historical scholarship as an argument presumes a finished product. But most time spent on historical scholarship is messy, involving rooting through Hollinger boxes, begging someone for 
an oral history interview, coughing through a shelf of city reports or directories, rereading notes, drafting manuscripts, sorting through critical comments, revising, and so forth. A published work does not materialize from a vacuum, and all that preceded and underlays it is legitimately part of historical work. Public presentations of history in the digital age reveal the extent of that "preargument" work, often in an explicitly demonstrative fashion or allowing an audience to work with evidence that is less directly accessible in a fixed, bound presentation. Digital history thus undresses the historical argument, showing that all our professional garments are clothing, even those not usually seen in public. As reviewer William Thomas observed, the digital age also allows scholars to scale up the extent of explicit argumentation, either by redesigning a project's public face or by inviting open commentary (as this volume has done). This capacity is more than accessorizing; it allows explicit, public reworking of argument.[23]

\section{Tools for Presentation of Artifacts and Events, Learning, and Argumentation}

Recognizing the breadth of presentation is separate from having trustworthy evaluation practices. Projects described above have won a number of awards, and yet, of the collection listed here, only Europe, Interrupted(and none of the award-winning projects) focuses on the type of argument that historians value in monographs published by university presses. Can we attach evaluative criteria to nonargument scholarship? The fields at the margins of history departments provide a partial solution, as academic historians in the post-World War II era have recognized the value of nonargument activities and functions. Public history is valued in theory, even if only a few history departments have faculty who engage in public history projects (and fewer who have earned tenure on that basis). Archivists are essential to the work of historians, but they are usually trained in schools that teach library or information sciences.[24] History faculty whose primary tool is archaeology have the ability to write methodological papers for specialist journals. If this pattern extends to digital history, one should expect that a few departments will devote significant resources to the formal training of digital history technicians, those who have programming skills and some disciplinary history background, and that most departments will struggle to evaluate digital history projects except where professional awards clearly convey peer approval.

But there need not be significant difficulty in understanding the contributions of digital history projects. As demonstrated in the projects described in this chapter or in the rest of this volume, academic historians have little problem recognizing the value of outstanding digital history work. The question is how to articulate the contributions of digital history in a way that is conceptual rather than ad hoc. We may use the existing outstanding digital history scholarship to generate those concepts, and the rest of this section catalogs an initial classification. 


\section{Tools to Present Artifacts}

There is a range of recognized professional presentations of historical artifacts, generally primary sources but also multimedia files. The Library of Congress American Memory project is the most extensive in North America, but both The Papers of George Washington and The Valley of the Shadow organize primary sources for an audience. The scope is different in each case: the Library of Congress (or a research library's special collections department) cares for and presents material from multiple collections in its custody, while an edited version of an individual's papers or a thematic collection is narrower in purpose as well as scope. The critical traits of an archival resource for historians include custodianship and proper sourcing, and the critical traits of an online presentation of historical artifacts parallel those: care of the digital resource and clear provenance. One can see similar parallels with edited collections of primary sources (a "Papers of . .." project), though in the case of The Papers of George Washington, it is clear that while the editing quality is the same for the (identical) hard copy and online main text, the public digital version is missing critical traits of annotation that historians expect of scholarly edited collections of quality.[25]

\section{Tools to Present Events}

A second general use of tools for digital history is the presentation of "events," or, more generally, specifics of history bounded by time and place. A number of tools exist for creating online time lines such as the SIMILE tool that has been incorporated into Google Docs or the EasyTimeline markup format in MediaWiki software.[26]One does not need an online tool to create a time line. But complex time and space data require specialized tools for presentation. The construction of historical maps has been an art form for centuries, generally beyond the recognized skill set of academic historians.[27] Hypercities has attracted considerable attention in the few years of its development, because it allows the presentation of data in a form that is attractive, thought-provoking, and conceptually simple, with successive layers representing change over time. One does not need to be an artist to use Hypercities, though the required digitization and geocoding tasks require time and attention to detail. One could also argue that statistical presentation is an equally important activity in presenting "events," if one considers a datum bounded by time and place, with presentation of statistical data being a skill often neglected in history departments. Gapminder is currently the most generally known infrastructure for presenting historical data series online in an attractive and conceptually simple manner.[28]

\section{Tools for Teaching and Learning}


Classroom-focused digital history projects can encompass an expanded/enriched textbook, a teaching portal with a range of resources, or other configurations. The construction of any website around learning is more than the appending of lesson plans to an existing website. It is the deliberate composition of resources that includes primary sources and support for activities that teachers might design or facilitate for students.

\section{Tools for Argumentation}

Tools for constructing arguments have begun to catch up with other digital technologies. Blogs have been a tool for short-form argumentation that has made self-publishing of short commentary accessible to individual scholars for more than a decade, but long-form or multimedia arguments have generally required specialized website construction until recently. Some blog tools, such as the WordPress plug-in Digress.it, now allow the publication of booklength projects with open commentary as the projects evolve (including the project that prompted this essay).[29] Omeka is a tool for online public history exhibits discussed earlier. Some of the more adventuresome university presses, such as the University of Michigan Press, have also explored different ways to extend the definition of the long-form argument beyond the hard-copy book.

As suggested earlier, historians will probably recognize the value of digital history in presentations of artifacts and sets of events and event representations when they contain the recognizable elements of quality work in offline parallels: care in custodianship and curation, tracking of provenance, match of organization with purpose, and accessibility of presentation. Such digital history projects may be viewed as inferior to long-form arguments unless they are adjuncts to scholarship that academic historians already recognize. But recognizing such projects as valuable scholarship does not require rethinking the fundamentals of historical work, since it matches up well to the traits of existing scholarly infrastructure for historians.

What requires more deliberate effort is the evaluation of scholarly work in creating tools and infrastructure. Here, an important consideration is the public visibility and use of the work. This is a pragmatic issue in terms of long-term impact as well as immediate value. Tools by themselves have little value as archived; because software quickly becomes outdated, a tool that is not used within a year or two will have no one providing feedback, no volunteers for further development, and no chance of support from potential funders. Yet, to gain users, most tools generally require a team that builds a community as well as creating a software package. 
This requirement of effective team building makes collaboration an essential part of tool building, which may be the most difficult criteria for historians to assimilate in evaluation, more than use. Historical scholarship generally operates as solo projects or as the product of very small teams of scholars. In contrast with those small teams, a much larger community is required by the development, persistent use, and maintenance of software packages such as Omeka or Zotero.[30] A history department at a research university may give tenure to an assistant professor who writes a single-authored book on an obscure topic with fewer than 200 copies sold, based on a university press's prospective valuation of the manuscript and postpublication review by a small number of senior scholars. But if assistant professors continue to work on a software package they contributed to as graduate students, that collaboration risks their careers, even if the software is used extensively by museums and historical sites and has a broader professional impact than narrow monographs. I suspect many history departments would gladly value a scholar who headed such a project, but historians find the contribution of other project members difficult to evaluate.

\section{Toward Bricolage or Narrative?}

In addition to the difficulty they encounter in evaluating collaboration in infrastructure, historians find the value of long-form arguments easier to evaluate as scholarship because the long-form argument contributes to historiographical discourse. As we construct arguments, we patch together ideas of our peers, trained by the practices of graduate education ("What is the contribution of this week's book?") and the ethics of citation ("Where did I read about that theory?"). In this discourse community, a peer's polished argument is labile feedstock. Should digital history projects thus shape their public sides closer to argumentation, to be digested and recycled by the bricoleur historian?[31]

There is more long-term value in maintaining a range of presentation of history in digital form than in trying to match contemporary writing habits too closely. It is not utopian to trust that bricoleurs will find value in pieces of digital history not presented as argument. It is not utopian to understand that while the definition of historical scholarship is centered heavily on the argument, there is an older tradition of history as narrative. It is not utopian to trust that if 20thcentury historians learned to become bricoleurs, 21st-century historians will use digital forms to modify both argument and narrative. This chapter addressed argument; the next addresses narrative.

\section{Notes}


1. For an example from oral history, see Alessandro Portelli, The Death of Luigi Trastulli, and Other Stories(Albany: SUNY Press, 1991). For the barest taste of more general historians' navelgazing, see Roy Rosenzweig and David Thelen, The Presence of the Past (New York: Columbia University Press, 1998); Joyce Oldham Appleby, Lynn Hunt, and Margaret Jacob, Telling the Truth about History (New York: W. W. Norton, 1994); Peter Charles Hoffer, Past Imperfect (New York: PublicAffairs, 2007); Jon Wiener, Historians in Trouble (New York: New Press, 2005). 會

2. This chapter focuses on both the professional dynamics in the United States and websites in English, but the argument is more general: we should see the diversity of successful digital projects everywhere as a way to talk about historical scholarship. 삼

3. The access (and business) models chosen by scholars heading projects do not always allow public access. The website for The Papers of George Washington, described in this chapter, requires institutional subscriptions for scholarly details. Subscriptions are also required to access the Women and Social Movements collections (described in this volume by Kathryn Kish Sklar and Thomas Dublin) or the tables and figures of the online Historical Statistics of the United States, Millennial Edition, ed. Susan B. Carter et al. (New York: Cambridge University Press, 2006), available at http://hsus.cambridge.org. 苦

4. Kathleen Fitzpatrick, Planned Obsolescence (New York: NYU Press, 2011). 술

5. Maris Vinovskis, From a Nation at Risk to No Child Left Behind (New York: Teachers College Press, 2008); Alex Stein, “The Teaching American History Program: An Introduction and Overview," History Teacher 36, no. 2 (2003): 178-85. .수

6. For a sample of the recent literature on such changes, see Derek Bok, Universities in the Marketplace (Princeton: Princeton University Press, 2004); David L. Kirp, Shakespeare, Einstein, and the Bottom Line (Cambridge, MA: Harvard University Press, 2004); Martha C. Nussbaum, Not for Profit (Princeton: Princeton University Press, 2010). 수

7. Ernest Boyer, Scholarship Reconsidered, 1st ed. (San Francisco: Jossey-Bass, 1997). 순 8. Working Group on Evaluating Public History Scholarship, "Tenure, Promotion, and the Publicly Engaged Academic Historian: A Report," AHA Perspectives, September 2010,http://www.historians.org/perspectives/issues/2010/1009/1009new3.cfm. 수

9. Arnold Toynbee and D. C. Somervell, A Study of History (New York: Dell, 1965), 295; National History Education Clearinghouse, "History Is an Argument about the Past" (poster), described in "Free Historical Thinking Poster!," August 17, 2010, http://teachinghistory.org/nhec-blog/24174/. . 순

10. There are also creditable digital history projects by amateurs, such as Phil Gyford's presentation of a 17th-century London source, "The Diary of Samuel Pepys," as a series of blog entries, at http://www.pepysdiary.com. The Internet advances the blurring of boundaries between 
academic and other production of history, a topic this volume's chapters on Wikipedia explore further.命

11. With some important exceptions, such as The Papers of George Washington and Women and Social Movements, digital history projects in the past decade have generally had publicly accessible online distribution. This essay does not discuss distinctions between public and subscription availability and related issues of ethics and business models. 令

12. Roy Rosenzweig, Steve Brier, and Joshua Brown, Who Built America? From the Centennial Celebration of 1876 to the Great War of 1914 (Santa Monica: Learning Technologies Interactive/Voyager, 1995), CD-ROM; American Social History Productions, Who Built America? From the Great War of 1914 to the Dawn of the Atomic Age in 1946(New York: Worth, 2000), CD-ROM.본

13. Daniel Jared Cohen and Roy Rosenzweig, Digital History (Philadelphia: University of Pennsylvania Press, 2006), chap. 7. 술

14. Edward L. Ayers, In the Presence of Mine Enemies (New York: W. W. Norton, 2003). 수 15. Michael O’Malley and Roy Rosenzweig, "Brave New World or Blind Alley? American History on the World Wide Web," Journal of American History 84, no. 1 (1997): 145. 수 16. Edward Ayers, The Valley of the Shadow: Two Communities in the Civil War, http://valley.lib.virginia.edu/. For this site, it is implied that the term archives refers to a static entity that will not be revised, rather than a living, curated collection of materials. 会 17. Library of Congress, "Mission and History," American Memory, http://memory.loc.gov/ammem/about/index.html. 荃

18. The Papers of George Washington, http://gwpapers.virginia.edu; Mount Vernon guest version,http://rotunda.upress.virginia.edu/founders/GEWN.xqy; Rotunda scholarly edition by subscription,http://rotunda.upress.virginia.edu/founders/GEWN. The project has received considerable support over the decades from the National Endowment of the Humanities and the National Historical Publications and Records Commission.수

19. Hypercities, http://hypercities.com or http://hypercities.ats.ucla.edu/; Ushahidi, http://www.u shahidi.com/; Philip Ethington, “Ghost Metropolis," Hypercities, 2011, available at http://hypercities.ats.ucla.edu. 수

20. Europe, Interrupted, http://www.inventingeurope.eu/invent/exhibits/show/europeinterrupted; Center for History and New Media, Omeka, http://omeka.org.수

21. American Social History Project and Center for History and New Media, History Matters, http://historymatters.gmu.edu/. 草

22. An online exhibit such as Europe, Interrupted is a relatively straightforward translation of long-form historical arguments to a hyperlinked environment, akin to a conventional, curated public history exhibit with a strong focus. 會 
23. Will Thomas, comment on Sherman Dorn, "Is (Digital) History More than an Argument about the Past?," inWriting History in the Digital Age, web-book ed. , Fall 2011 version. This undressing also demonstrates how historians make choices as they fashion scholarship; for more on selection and silencing, see, for example, David William Cohen, The Combing of History (Chicago: University of Chicago Press, 1994); Michel-Rolph Trouillot,Silencing the Past (Boston: Beacon, 1995), especially chap. 1.수

24. The Directory of Archival Education of the Society of American Archivists (http://www2.archivists.org/dae) lists seven archival degree programs located in history departments. 柁

25. A separate issue is the organization of such artifacts, and I recognize that one could argue that an exhibit using Omeka is also a presentation of artifacts. 亚

26. Semantic Interoperability of Metadata and Information in unLike Environments (SIMILE) project, SIMILE software (Massachusetts Institute of Technology), available at http://www.simile-widgets.org/timeline/; WikiMedia Foundation, EasyTimeline extension, http://www.mediawiki.org/wiki/Extension:EasyTimeline. .草

27. The classic is Charles Joseph Minard's display of Napoleon's march into and out of Moscow. See Edward R. Tufte, The Visual Display of Quantitative Information, 2nd ed. (Cheshire, CT: Graphics, 2001), 40-41. See also, more generally, Daniel Rosenberg and Anthony Grafton, Cartographies of Time (New York: Princeton Architectural Press, 2010). 숭 28. Gapminder Foundation, Gapminder software, available at http://gapminder.org. 荅 29. WordPress Digress.it plugin, http://digress.it. 수

30. These software packages produced by the Rosenzweig Center for History and New Media are available athttp://www.omeka.org and http://www.zotero.org, respectively.순 31. See comments by William Thomas and Timothy Burke on Sherman Dorn, "Is (Digital) History More than an Argument about the Past?," in Writing History in the Digital Age, webbook ed., Fall 2011 version; James E. Porter, "Intertextuality and the Discourse Community," Rhetoric Review 5 (1986): 34-47.수 